\title{
INVESTIGATION OF VIRGIN AND RECYCLED ROTOMOLDED POLYETHYLENE USING X-RAY DIFFRACTION AND X-RAY FLUORESCENCE
}

\author{
Brandão, A. S.*; de Melo, S. L. S. and de Deus, E. P. \\ Department of Eng. and Science Materials, University Federal of Ceará, Fortaleza, Ceará, Brazil
}

*abrandao@fanor.edu.br

\begin{abstract}
According to the European Union, from 1950 to 2012, the plastics industry is growing at a logarithmic scale, where the polyethylene (PE) is a leader in the demand for plastic resins, 29.5\%. In Brazil, according to ABIPLAST, the demand reaches $39 \%$. The aim of this paper is to make a comparative analysis between virgin and recycled rotomolded PE, by using the characterization techniques for materials such as X-Ray diffraction (XRD) and fluorescence (XRF). XRD measurements were performed of waste generated by testing filler content (qualitative analysis of the crystalline phase present) and micronized raw material, to find the crystallinity of the material. As for the XRF measurements were conducted of waste generated from the content of the test load (semi-quantitative analysis of the elements present) as well as the raw materials before and after processing of the material (rotomold), in order to find out what kind of loads are being incorporated. Through the techniques of XRD it was found that the virgin material is slightly more crystalline than recycled, 55\% and 54.64\% respectively, with the results validated test thermal analysis, differential scanning calorimetry (DSC). In XRF assays for raw materials there is a significant presence of the following elements: titanium, calcium, silicon and aluminum. Thus, it is concluded that the virgin material is more susceptible to fragile fracture, being more crystalline. It was also concluded that were added elements to improve workability (calcite-magnesium, $\left(\mathrm{Mg}_{0,03} \mathrm{Ca}_{0,97}\right) \mathrm{CO}_{3}$ ), mechanical performance/chemical resistance (Lazurite, $\mathrm{Na}_{8,56}$ $\left.\left(\mathrm{Al}_{6} \mathrm{Si}_{6} \mathrm{O}_{24}\right)\left(\mathrm{SO}_{4}\right)_{1,56} \mathrm{~S}_{0,44}\right)$ and photodegradation resistance (rutile, $\left.\mathrm{TiO}_{2}\right)$.
\end{abstract}

